\title{
KATEKISASI BERKALA DI JEMAAT BAFUAYA KABUPATEN DONGGALA SULAWESI SELATAN SEBAGAI PERSIAPAN MEMASUKI KEHIDUPAN BARU SEBAGAI ORANG PERCAYA
}

\author{
Moses Wibowo, Tony Salurante, Juliana Nurtita, Romuba Simamora dan Hendrikus Kombok \\ Sekolah Tinggi Teologi Injili Arastamar (SETIA) Jakarta
}

\begin{abstract}
Abstrak
Katekisasi sudah banyak diabaikan oleh banyak gereja. Dalam penelitian Pengabdian kepada masyarakat ini team mengimplementasikan tradisi ini sebagai sebuah usaha awal dalam mengajar firman Tuhan kepada jemaat suku Kaili-Daa di dusun Bavuaya. Katekisasi merupakan metode yang digunakan yang cocok dengan karakter dan latarbelakang konteksnya. Hasil yang dicapai dalam kegiatan ini cukup signifikan, tidak hanya belajar firman Tuhan namun Pendidikan lain juga terserap karena metode tanya jawab dan persekutuan yang intensif membuat jemaat yang dahulunya sangat tertutup lambat laun menjadi terbuka. Kesempatan seperti ini sebuah langkah yang berat itu sebabnya dilakukan cukup lama.
\end{abstract}

\section{Kata Kunci: Katekisasi, Suku Kaili Daa, Penginjilan, suku terabaikan}

\section{PENDAHULUAN}

Salah satu pesan terakhir yang dituturkan oleh Tuhan Yesus selama di bumi dan menjelang kenaikan-Nya ke surga adalah mengenai "Katekisasi:"

${ }^{19}$ Karena itu pergilah, jadikanlah semua bangsa murid-Ku dan baptislah mereka dalam nama Bapa dan Anak dan Roh Kudus, 20 dan ajarlah mereka melakukan segala sesuatu yang telah Kuperintahkan kepadamu. (Mat 28:19-20)

Pengajaran kepada umat adalah salah satu tantangan yang dihadapi orang percaya sebagai seseorang yang telah percaya diperlukan untuk megalami pertumbuhan iman. Bertumbuhnya iman umat tergantung kepada kualifikasi pengajaran dan juga pengajaran itu sendiri. Ini adalah suatu tugas dan tugas ini datang dari Tuhan Yesus sendiri. Katekisasi sendiri bisa dilakukan kepada orang dewasa dan anak-anak dan hal ini adalah tangung jawab gereja. ${ }^{1}$

Model Alkitab tentang katekisasi adalah memuridkan: Yesus mengajar di rumah-rumah ibadat, di Bait Allah di Yerusalem, di kota-kota besar dan kecil, di tepi laut; ia berbicara kepada murid-murid, orang-orang Farisi dan orang banyak tanpa pandang bulu. Surat-surat pastoral menekankan pengajaran berbasis tulisan suci.

\footnotetext{
${ }^{1}$ G. Riemer, Ajarlah Mereka:Pedoman Ilmu Katekese (Jakarta: Yayasan Komunikasi Bina Kasih/OMF,
} 1998), 7-11. 
Secara etimologi katekisasi berelasi dengan katekese dan kateketik yang berasal dari kata bahasa Yunani "katekhein". Makna utama dari kata ini oritorisasi yang sahih dalam memberikan Pendidikan atau pengajaran. Karena kata "katekhein" berarti mengajar dari atas ke bawah. Di dalam dalamnya mengandung aspek otoritasi tetapi juga mengandung aspek reaksi sehingga terwujud dalam sebuah dialogis. Oleh karena itu dapat disimpukan bahwa "katekhein" adalah memproklamasikan sesuatu dengan otrisasi yang sahih dan dengan cara dialogis. ${ }^{2}$

Model klasiknya dari katekisasi adalah menciptakan katekumenat: pengorganisasian seperti itu menjadi penting seiring dengan meningkatnya jumlah anggota gereja, penyebaran geografis mereka dan peningkatan ajaran sesat, tetapi juga karena penganiayaan oleh Negara dan permusuhan masyarakat (band. KPR. 18:25; 1 Kor. 14:19; Rom. 2:18 dan Gal. 6:6). Pertumbuhan iman menjadi kebutuhan mendasar umat dan hal ini bisa terwujud jika umat memahami iman mereka. Kondisi ini akan terwujud melalui katekisasi yang mengasilkan pemahaman iman Kristen yang benar karena kita semua terpanggil untuk mengaku iman. Setiap umat harus diajar dengan materi yang berkaitan dengan apa yang mereka percayai tentang TUHAN yang berkarya melalui Yesus Kritus dalam prespektif trinitarian (bapa, anak dan roh kudus) dalam relasi manusia yang telah jatuh kedalam dosan. Akan tetapi oleh kasih karunia TUHAN beroleh keselamatan dan harus hidup sesuai apa yang mereka Imani. Semua materi iman ini hanya pertolah dari kitab suci yang membicarakan tentan karya penyelamatan, mulai dari penciptaan sampai dengan kedatangan Yesus Kembali. ${ }^{3}$

Menjangkau yang tidak terjangkau merupakan spirit yang digelorakan untuk mengasihi orang-orang yang terabaikan. Salah satu lokasi yang belum terjangkau di Sulawesi Tengah adalah dusun Bavuaya di Desa Pinenbani Kabupaten Donggala. Penduduk Bavuaya dan kampung-kampung lainnya masih hidup secara nomanden. Mereka bercocok tanam dilereng-lereng gunung setiap tahunnya. Masyarakat di dusun Bavuaya merupakan orang-orang keturunan dari suku Kaili-Daa yang banyak tersebar di Sulawesi Tengah banyak tersebar diseluruh pegunungan. Ciri-ciri mereka adalah hidup di rumah pohon.

Masyarakat yang hidup disekitar penggunungan tersebut masih jauh dari peradaban. Mereka bukan saja buta huruf dan tertinggal tetapi juga tergolong animis. Sekalipun mereka beragama Kristen. Kampung ini terdiri dari Usia lanjut tergolong sangat karena usia mereka tidak ada yang bisa lebih dari 50 tahun. Salah satu faktor karena

\footnotetext{
${ }^{2}$ Riemer, Katekisasi, 21.

${ }^{3}$ Materi ini dapat diambil dari pengakuan iman Wesminster dalam buku Enam Belas Dokumen Dasar Calvinisme, 56-140
} 
pengetahuan, pelayanan, kesadaran tentang hidup sehat dan kesehatan yang tergolong minim. Jika melihat berbagai ciri umum suku-suku terasing tidak berpendidikan, hidup berpindah-pindah, tidak

berbahasa Indonesia, pola kesehatan yang buruk dengan demikian masyarakat yang hidup di pegunungan rimba termasuk suku terasing yang belum terdeteksi. Sekalipun mereka bisa termasuk dalam Suku Da'a atau Kaili sebagai suku-suku yang tersebar di Sulawesi

Tengah.

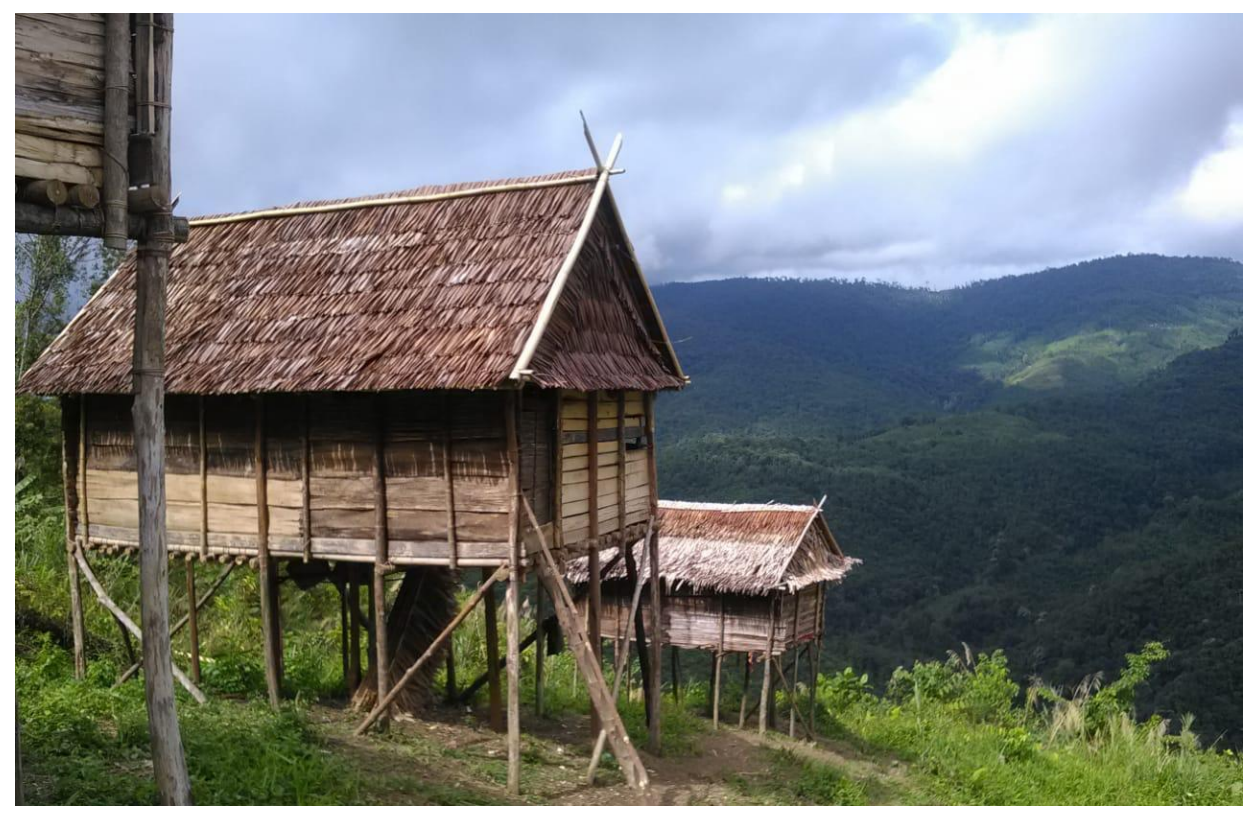

\section{Gambar 1. Rumah penduduk di Bavuaya}

Kegiatan ini merupakan bentuk dalam mengimplementasikan misi dari Sekolah Tinggi Teologi Injili Arastamar (SETIA) Jakarta melalui berperan aktif dalam aktifitas pemberdayaan maka akan mengadakan pembinaan imam melalui kegiatan katekisasi secara berkala kepada umat di Bavuaya dengan bekerjasama dengan Sinode Gereja Kristen Setia Indonesia (GKSI) untuk melaksanakan katekisasi dan pada akhrinya beroleh pelayanan baptisan kepada mereka yang telah mengikuti katekisasi secara berkala. ${ }^{4}$

\section{METODE PELAKSANAAN}

\footnotetext{
${ }^{4}$ Sinode GKSI menyediakan SDM Pembina dan juga Pendeta untuk menjalankan katekisasi berkala dan baptisan serta buku pedoman katekisasi dan pelaksanaan baptisan.
} 
Bavuaya merupakan dusun terpencil dan terasing, oleh karena itu persiapan sebelum melaksanakan kegiatan ini harus direncanakan dengan sematang mungkin. Selain itu waktu yang panjang juga menjadi pertimbangan untuk melibatkan beberapa orang dalam 2 tahap. Metode Pelaksanaan dibagi menjadi 3 yaitu Persiapan, pelaksanaan dan Evaluasi.

\section{a. Persiapan dan Pembekalan}

1. Sebelum melakukan kegiatan katekisasi di Dusun terasing Bavuaya diperlukan persiapan sejak tahun 2018. Melalui Pendidikan bagi 2 orang mahasiswa pertama yang akan diutus terlebih dahulu. Juliana Nurtina Silitonga dan Romuba Simamora memperdalam pengetahuan kontekstualisasi dan katekisasi. Selama 1 bulan mereka mendapatkan pembekalan sebelum diutus. Kegiatan ini berbarengan dengan ikatan dinas mereka sebagai alumni. Tugas utama mereka yang lain adalah menjalin relasi sehingga setelah 1 tahun diharapkan sudah terjalin hubungan yang baik.

2. Persiapan materi yang disesuaikan dengan berbagai informasi yang dikirim oleh 2 orang di Bavuaya. Bahan-bahan yang tersedia menjadi sumber dikaji ulang dan mengalami penyesuaian dalam segi bahasa setempat.

3. Pada tahun 2019 bulan Februari diutus kembali Esau Kebo dan Hendrikus Kombok yang akan melaksanakan kegiatan katekisasi berkala kepada masyarakat yang sudah membuka diri untuk dilayani.

\section{b. Pelaksanaan}

1. Sejak bulan Maret 2019 kegiatan katekisasi dengan menggunakan buku Katekismus Singkat Westminster

2. Dilaksanakan selama 1 tahun diikuti oleh 82 orang dewasa berumur 20-55 tahun.

3. Kegiatan katekisasi di bagi menjadi 4 kelompok. Selain umur yang menjadi dasar, termasuk juga gender.

4. Jumlah masyarakat 120 jiwa, $28 \mathrm{KK}$, anak-anak 50 anak dan totang jumlah yang dibaptis 72 orang. 


\section{HASIL DAN PEMBAHASAN}

\section{Tahap 1}

Dusun Bavuaya pertama kali dikunjungi pada tahun 2017 ketika kegiatan Mission Trip Mahasiswa STT SETIA Jakarta dilaksanakan. Perintisan dlakukan pertama kali oleh Agustinus yang saat masih menjadi mahasiswa praktik. Lalu kunjungan kedua dan sekaligus pembukaan Pos PI GKSI (Gereja Kristen Setia Indonesia) dilakukan oleh Tony Salurante, Riswan dan Hendrik Irawan yang kebetulan sebagai pengurus Yayasan Sabas dan ikut mampu ikut berjalan menuju dusun tersebut. Setelah perijinan dipenuhi di tingkat desa maka dusun Bavuaya resmi menjadi Pos ke dua di Kabupaten Donggala

\section{Tahap 2}

Perintisan Pos PI di wilayah suku-suku pedalaman seperti ini tidak bisa dikerjakan sendiri. Sejak 2018 STT Setia Jakarta menerima dukungan dari 2 Gereja di Jakarta (GKI Kav. Polri Jakarta Barat dan GKI Kota Wisata Cibubur) untuk menopang pembangunan yang direncanakan. Hal pertama yang dibangun adalah pastori untuk tempat tinggal mahasiswa maupun alumni. Dari sini dimulailah Pendidikan dasar bagi anak-anak yang $100 \%$ saat itu tidak bisa membaca dan tidak seluruhnya bisa berbahasa Indonesia. Ada 2 mahasiswa dari STT Star's Lub Luwuk Banggai yang mengawali pembinaan yaitu Jupri Yundu dan Fano. Dipertengah 2018 maka diutus 2 alumni untuk berkontribusi lebih besar lagi yaitu Romuba Simamora dan Juliana Nurtita. 2 alumni tersebut telah menerima pembimbingan khusus dari 2 dosen di STT Setia Jakarta yaitu Moses Wibowo dan Tony Salurante selama 3 bulan. Inilah tahap awal dari katekisasi jemaat di Pos PI GKSI di kabupaten Donggala.

\section{Tahap 3}


Tahap selanjutnya kegiatan katekisasi dilakukan seminggu 2 kali pada hari rabu dan minggu sore. Keduanya menggunakan buku Katekismu Singkat Westminster 1 dan 2 karangan G.I Williamson terbitan Momentum. Buku ini menjadi pedoman bagi para pengajar bagi kaum dewasa di dusun Bavuaya. Kegiatan ini dilaksanakan selama 1 tahun.

\section{Tahap 4: Kunjungan 1}

Ditengah pertengahan periode selanjutnya 2 dosen dari Jakarta yaitu Tony Salurante dan Malik melakukan perkunjungan ke Bavuaya. Hal ini dilakukan sebagai monitoring pelayanan dalam menjalankan Tridharma dalam hal Pengabdian kepada Masyarakat. Beberapa hal yang dilaksanakan selama monitoring terdiri antara lain:

1. Diskusi tentang masalah dan hambatan dalam mengajar di suku terabaikan

2. Berdoa bersama dan

3. Persekutuan dengan jemaat.

\section{Tahap 5: Baptisan}

Baptisan merupakan langkah terakhir setelah terpenuhi sebagian besar pelajaran dari buku Katekismus. Ada sekitar 60 pelajaran (pertanyaan) yang diajarkan berkali-kali kepada masyrakat. Sekalipun Bahasa menjadi tantangan namun masalah tersebut bisa di atasi karena ada penterjemah. Setelah melakukannya selama 1 tahun pada akhirnya sebagian besar menerima baptisan sebanyak 82 orang dewasa.

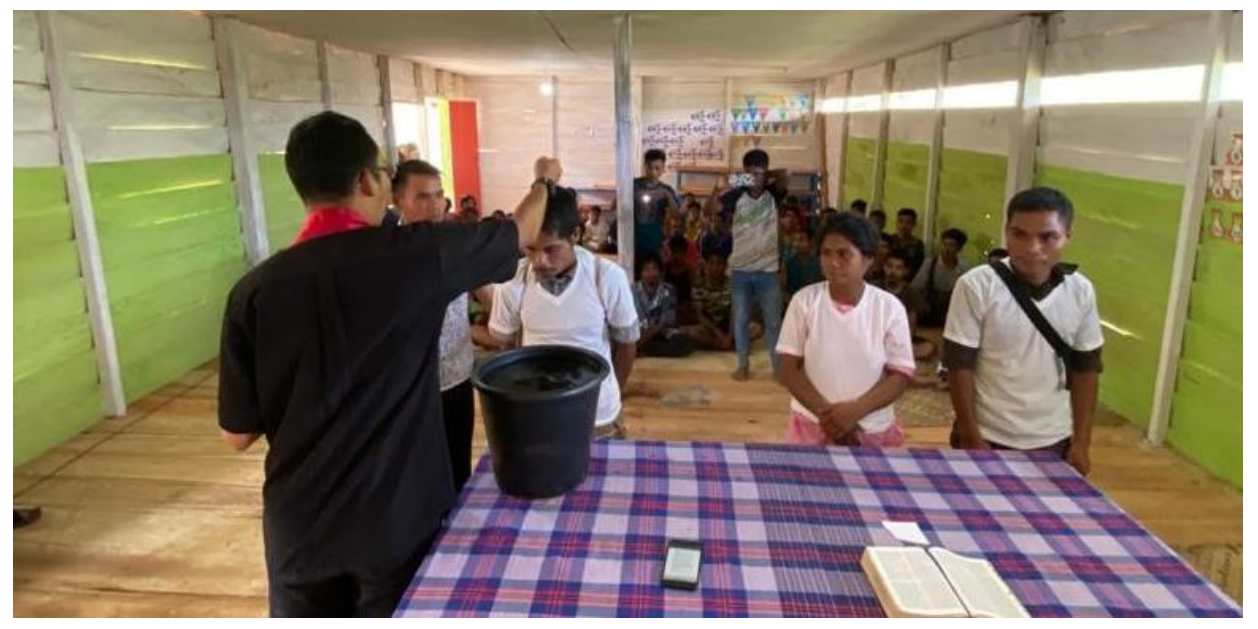




\section{Gambar 2. Baptisan percik dilaksanakan secara masal.}

\section{KESIMPULAN}

Katekisasi masih diperlukan dalam membina iman jemaat dan membawa mereka mengerti apa yang mereka percaya. Tanpa katekisasi yang berkala dan berkesinambungan maka pertumbuhan iman bagi suku Da'a/Kaili di Bavuaya akan menghadapi kendala besar. Dengan dimulainya katekisasi ini maka terbukti memberikan hasil yang signifikan. 20 orang mengerti dan memahami artinya Tuhan menciptakan manusia. 50 orang mengerti dengan baik apa artinya dosa. Tidak ada cara singkat untuk kita belajar untuk mengenal Allah yang sejati.

Setelah mereka memiliki pengertian dan kesadaran yang timbul karena pimpinan Roh Kudus, mereka menyerahkan diri untuk menerima baptisan. Dampak lain dari kegiatan katekisasi berkala ini, masyarakat jadi peduli akan kehidupan, rajin beribadah, rajin belajar membaca dan menulis sekalipun sudah ada yang tua.

\section{DAFTAR PUSTAKA}

Luther, Martin. Katekismus Besar. Terj. Anwar Tjen. Jakarta: BPK Gunung Mulia, 2011.

Meade, Starr. Membentuk Hati, Mendidik Akal Budi. Terj. Andiana M. Rorimpandey. Surabaya: Momentum, 20062003.

Packer, J. I. Penginjilan dan Kedaulatan Allah. Surabaya: Momentum. 2014

Riemer, G. Ajarlah Mereka:Pedoman Ilmu Katekese. Jakarta: Yayasan Komunikasi Bina Kasih/OMF, 1998.

Van den End, Th, Enam Belas Dokumen Dasar Calvinisme. Jakarta: BPK Gunung Mulia, 2011.

Sinode GKSI, "buku pedoman dan liturgi GKSI." Jakarta: Delima, 2010.

Williamson, G.I. Katekismus Singkat Westminster 1. Surabaya: Momentum, 2006.

-------------. Katekismus Singkat Westminster 2. Surabaya: Momentum, 2006. 